\title{
Reseña. Regina Dalcastagnè, Representación y resistencia en la literatura brasileña contemporánea. Trad. Lucía Tennina y Adrián Dubinsky. Buenos Aires: Editorial Bilbos, 2015.
}

What is literature? In her latest work, Representación y resistencia en la literatura brasileña contemporánea, Regina Dalcastagnè responds to this question by interrogating literature as a social construct that acts as both producer and product of systems of social inequality. Critiquing the portrayal of literature as a perfect art form exempt from ideological contamination, Representación y resistencia argues that literature is neither better nor worse than society, but rather part of society, and as such, is shaped by many of the same hierarchies, exclusions and inequalities, which define our world. Yet, it is this same existence as a societal construction that imbues literature with the potential to operate as a democratizing force. This duality guides this book's investigation of literature as a contested territory where questions of literary representation intersect with struggles over political and cultural representation, and where resistance to one's own literary erasure requires an equally impressive variety of tactics and strategies as those employed by social movements. 
CATEDRAL Tomada: Revista de crítica literaria latinoamericana / Journal of Latin American Literary Criticism Reseña. Regina Dalcastagnè, Representación y resistencia en la literatura brasileña contemporánea. Trad. Lucía Tennina y Adrián Dubinsky. Buenos Aires: Editorial Bilbos, 2015.

To narrow the scope of this work's general framing of literature and society, Representación y resistencia limits its analysis to contemporary Brazilian literature-defined by Dalcastagnè as novels published within the last 50 years (1965-2015). Within this limited time frame, this scholarly work undertakes a detailed qualitative analysis of exemplary pieces of contemporary Brazilian literature and an equally exhaustive quantitative analysis of all Brazilian literature published by the nation's three main publishing houses. This combined methodological approach, rarely seen in literary criticism, complements the book's central inquiries in two ways. Initially, it provides a statistical overview of whom Brazilian contemporary literature includes and excludes from its pages. Complementarily, Dalcastagnè's close-textual analysis examines the specific ways in which these (non-)existent literary representations may challenge the homogenous representations that dominate Brazilian literature and/or reinforce literature's inequalities and hierarchies of representation. Thus, while Dalcastagnè offers an impressive big-N study of who writes, narrates, and holds the protagonist role in mainstream Brazilian literature, she perhaps more importantly sets the stage for the book's profound discussion of what it means to be represented and how literature and other artistic mediums forced to operate within an imperfect system may ethically and effectively challenge Brazil's erasure of marginalized bodies.

Divided into 7 chapters, Representación y resistencia discusses the various problematics associated with the lack of representation of these marginalized communities. The opening chapter proposes a reconsideration of Brazilian literature's representation of the "other" by classifying these attempts at representation as either 1) "exotic", 2) "critical", or 3) "from within" (Dalcastagnè 25). While the first two classifications tend to fall under the first of Judy Giles and Tim Middleton's definitions of representation as an act in which one speaks or operates on the behalf of someone else, the final classification is more associated with the concept of re-presenting experiences of authors who self-identify as "other" (63). Despite these different relationships to the act of representation, all 
three categories dialogue with the issue of authenticity. Inauthentic in their attempt to represent that which is other, "exotic" and "critical" approaches to representation diverge on how and if to recognize this inauthenticity. Specifically, it is the productive use of uncomfortableness by the latter critical approach, which can act as a conscious-raising effort in the fight to democratize Brazilian literature. On the flip side, it is the authenticity associated with works written "from within" that, according to Dalcastagnè, can be equally as detrimental to this democratization movement. Often viewed as less esthetic and qualified as niche books, works such as Quarto de despejo by Carolina Maria de Jesus are frequently disqualified from the realm of literature precisely because of this authenticity.

Dalcastagnè's next three chapters offer a more in-depth analysis of the problems inherent in writing the other and the tendency to deprive marginalized authors of the right to write with literary authority. The book's second chapter is where Dalcastagnè's previously noted quantitative analysis plays a central role in providing statistical evidence of the large absence of Brazil's black population from the nation's literature, an absence, which is furthered reinforced by the literary norms that it in turn constructs. Approximately $80 \%$ of all characters studied within the nearly 400 novels included in this statistical analysis were found to be white. This figure positions Brazilian novels that incorporate black characters as the literary exemption. However, not content with leaving the "inclusive" $20 \%$ unquestioned, this book's powerful critique shines as it carefully unpacks the underlying racism and imperfect parodies that constitute many of the stereotypical black representations in contemporary Brazilian literature. Offering a concrete, if perhaps necessarily partial, solution to the problem, Representación y resistencia calls for writing black characters and incorporating critiques of racial inequality into the structure of the narrative and thus opening up a space for reader interaction with a new form of narrative structure that works to offer more representative representations. This narrative structure is further complemented by embracing the uncomfortableness that stems from every crisis of 
CATEDRAL Tomada: Revista de crítica literaria latinoamericana / Journal of Latin American Literary Criticism Reseña. Regina Dalcastagnè, Representación y resistencia en la literatura brasileña contemporánea. Trad. Lucía Tennina y Adrián Dubinsky. Buenos Aires: Editorial Bilbos, 2015.

representation and impossibility of writing the un-representable, and aesthetically evoking these realizations in the reader.

The fifth chapter of Dalcastagnè's Representación y resistencia bridges the role and responsibilities of the contemporary reader with the changing landscape of the contemporary narrator. Thus, this chapter provides a chronology of sorts that reflects on the recent trends in narrative style within late $20^{\text {th }}$ and early $21^{\text {st }}$ century Brazilian literature, all couched within a discussion of how the narrators attempt to transform themselves from passive object to active subject through writing. As Dalcastagnè argues, despite the homogenous nature of many of the representations that remain central to the racial, class and gender composition of Brazilian literature, Brazilian literature has evolved in recent decades. It has become an art form more focused on movement within the relative stagnation of its metropolitan-centered narratives, more welcoming of fragmentation despite the omnipresence of white, male, middle-class protagonists, and more demanding of readers, who are forced to participate in the narrative construction of novels and the questioning of narratives truths. It is this last point where the fifth section truly begins to find its place within Dalcastagnè's larger argument. She posits that all representations that justify their existence by citing reality perpetuate systematic violence through their selective-nature and imposition of order, which quiet certain characteristics and accentuate others. However, when readers are invited to question literature's artifice, some of this violence may be mitigated.

The ordering carried out via representation is explored in its spatial dimension in the text's final two chapters. The first of these chapters analyzes the spatial cartographies constructed within contemporary Brazilian literature, which both create and reflect the social imaginaries of the nation. These mappings act simultaneously as a foundation that structures social identities, and the façade behind which these constructions mask their ideological intentions as reality. In their current iteration, they claim to focus on Brazil's urbanization and the new metropolis-presented as largely masculine-and to normalize the division of 
private and public. Two articulations that are in themselves political acts, their selective inclusion of certain scenarios reinforces the marginalization of liminal spaces and eliminates those spaces deemed "off-limits." This dual act of elimination and exclusion reinforces Dalcastagnè's initial argument regarding the exclusions inherent in the large majority of Brazil's recent literary attempts to represent the nation. However, just as this literature has the potential to operate as a tool of spatial segregation, it also has the ability to call attention to frequently unperceived forms of structural violence. As Dalcastagnè states, "Es ante esa violencia que acostumbramos a cerrar a los ojos y que la literatura, o al menos parte de ella, puede hacernos ver" (153). Those novels that make us conscious of this violence through the portrayal of bodies that move through space insisting on occupying spaces that were not "meant for them" and resisting the imposition of the dominate discourse on their individual stories, these are the novels lauded by this text and explored in detail in these final two chapters.

In the end, Dalcastagnè literary critique carefully weaves together seemingly disparate chapters by using each to enter deeper into her investigation of how representation is carried out and what it means to be represented or made invisible. While each chapter presents a unique perspective on the impossibilities of representation, its constructive nature, its relationship with reality, and the role of language and space in its eventual cementation, together these chapters expound upon the various avenues through which the democratization of literature may be worked towards. Representación y resistencia proposed solutions include the invention of new literary structures that are more responsive to the needs of marginalized groups, the conscious-raising efforts of authors who point out the ethical implications of their own representations of the other, and an increase in the accessibility of certain novels. On this latter point, Dalcastagnè truly practices what she preaches by using language in a way that both highlights her own understanding of the field of literary criticism and insuring accessibility. She writes in a way that is largely free of the jargon and the forced academic 
CATEDRAL TOMADA: Revista de crítica literaria latinoamericana / Journal of Latin American Literary Criticism Reseña. Regina Dalcastagnè, Representación y resistencia en la literatura brasileña contemporánea. Trad. Lucía Tennina y Adrián Dubinsky. Buenos Aires: Editorial Bilbos, 2015.

complexity that in many ways perpetuates structural inequalities by allowing for total understanding by some and limited access for many.

Representación y resistencia is a carefully crafted piece of literary criticism that effectively analyzes current trends in Brazilian literature through an interrogation of the problems and silences inherent in representation. In this way, the text operates on two-levels. The first level highlights how Brazil is written, which as Dalcastagnè's concludes, largely silences those voices that are already excluded from the nation's other spaces of discourse production (200). This potential to foment and re-enforce exclusions contrasts with literature's equally powerful ability to function as space of democratization. Driven by this focus on literature's necessary democratization, the text's secondary sociopolitical inquiry forwards a socially aware vision of what constitutes literature. This book, thus, acts as a rich terrain for discussions relevant to literary criticism and debates on sociopolitical inequality. One such discussion may be the potential doubts raised by Dalcastagnè's defense of this democratization in relation to the resources referenced within her text, including the relative exclusion of alternative literary forms from the book's qualitative analysis. While Dalcastagnè does not ignore the existence of these other avenues of literary production - referencing rap, Brazil's saraus and other alternative media as new literary forms of insurgent citizenship - it is important to ponder how this book's analysis may have been further shaped by the incorporation of these texts within her body of examples. A matter that is perhaps beyond the scope of an already broad, effective analysis of the lack of complex representations of marginalized communities in Brazilian literature, the effects of this exclusion is a fertile terrain for further analysis. This future avenue for investigation complements Representación y resistencia's own major contribution to the field as both a piece of literary criticism and a treatise of social justice; for in the end, this key piece of literary criticism reaches beyond the traditional realm of literary studies by exemplifying the field's interdisciplinary reach and its impact as a tool for understanding how humans write, represent, and construct the world around them. 
CATEDRAL TOMADA: Revista literaria latinoamericana / Journal of Latin American Literary Criticism Amy Cosimini

\section{Work Cited}

Dalcastagnè, Regina. Representación y resistencia en la literatura brasileña contemporánea. Trans. Lucía Tennina and Adrián Dubinsky. Buenos Aires: Editorial Bilbos, 2015. Print.

Giles, Judy and Tim Middleton. Studying Culture: A Practical Introduction. $2^{\text {nd }}$ ed. Oxford: Blackwell, 2002. Print. 